\title{
Effect of temporal averaging of meteorological data on predictions of groundwater recharge
}

\author{
Marcia S. Batalha ${ }^{1}$, Maria C. Barbosa ${ }^{1}$, Boris Faybishenko ${ }^{2}$, Martinus Th. van Genuchten ${ }^{3,4 *}$ \\ ${ }^{1}$ Department of Civil Engineering, Federal University of Rio de Janeiro, UFRJ, Rio de Janeiro, RJ, Brazil. \\ ${ }^{2}$ Lawrence Berkeley National Laboratory, Berkeley, California, CA, USA. \\ ${ }^{3}$ Center for Environmental Studies, CEA, São Paulo State University, UNESP, Rio Claro, SP, Brazil. \\ ${ }^{4}$ Department of Earth Sciences, Utrecht University, Utrecht, Netherlands. \\ * Corresponding author. E-mail: rvangenuchten@hotmail.com
}

\begin{abstract}
Accurate estimates of infiltration and groundwater recharge are critical for many hydrologic, agricultural and environmental applications. Anticipated climate change in many regions of the world, especially in tropical areas, is expected to increase the frequency of high-intensity, short-duration precipitation events, which in turn will affect the groundwater recharge rate. Estimates of recharge are often obtained using monthly or even annually averaged meteorological time series data. In this study we employed the HYDRUS-1D software package to assess the sensitivity of groundwater recharge calculations to using meteorological time series of different temporal resolutions (i.e., hourly, daily, weekly, monthly and yearly averaged precipitation and potential evaporation rates). Calculations were applied to three sites in Brazil having different climatological conditions: a tropical savanna (the Cerrado), a humid subtropical area (the temperate southern part of Brazil), and a very wet tropical area (Amazonia). To simplify our current analysis, we did not consider any land use effects by ignoring root water uptake. Temporal averaging of meteorological data was found to lead to significant bias in predictions of groundwater recharge, with much greater estimated recharge rates in case of very uneven temporal rainfall distributions during the year involving distinct wet and dry seasons. For example, at the Cerrado site, using daily averaged data produced recharge rates of up to 9 times greater than using yearly averaged data. In all cases, an increase in the time of averaging of meteorological data led to lower estimates of groundwater recharge, especially at sites having coarse-textured soils. Our results show that temporal averaging limits the ability of simulations to predict deep penetration of moisture in response to precipitation, so that water remains in the upper part of the vadose zone subject to upward flow and evaporation.
\end{abstract}

Keywords: Groundwater recharge; Meteorological data; Temporal averaging; HYDRUS-1D; Infiltration; Evaporation.

\section{INTRODUCTION}

Having accurate estimates of water flow rates into and through the vadose zone, and related groundwater recharge rates, is critical in many hydrologic, environmental agricultural applications such as surface- and ground-water management, management and remediation of contaminated soils and groundwater, and irrigation and drainage operations in agriculture. As groundwater is increasingly being used, and available resources are slowly diminishing in many parts of the world, a critical need exists to develop sustainable groundwater use and management practices (Gleeson et al., 2015; Shah et al., 2000; Shiklomanov, 1997; Vörösmarty et al., 2000). This in turn requires an accurate quantitative understanding of the fundamental meteorological controls on groundwater recharge under conditions of climate change (Gorelick and Zheng, 2015; Maxwell and Kollet, 2008; Veldkamp et al., 2016). Groundwater depletion currently occurs in many arid and semi-arid areas due to excessive extraction, especially for irrigation (Aeschbach-Hertig and Gleeson, 2012), with global change exacerbating this problem in various parts of the world.

The expected intensification of precipitation due to global climate change, with a shift toward more heavy precipitation events of often short duration, may lead to an increase in groundwater recharge in tropical and other areas (Allan et al., 2010; Jasechko and Taylor, 2015; Owor et al., 2009). Failure to consider realistic changes in precipitation intensity can influence predictions of both climate change and groundwater recharge (Gee and Hillel, 1988; Mileham et al. 2009; Owor et al.,
2009). Intense rainfall events may lead to episodic recharge events (Taylor et al., 2013), which are not accounted for in calculations of groundwater recharge when using monthly or especially annually averaged (aggregated) meteorological time series data, such as is the case with large-scale and long-time averaged water balance equations (Shiklomanov and Rodda, 2003) or using other methods (Kim and Jackson, 2012; Phillips, 1994; Scanlon et al., 2002).

Predictions of water flow into and through the vadose zone contributing to groundwater recharge are dependent upon the availability of meteorological data sets. Data of this type are often obtained from weather stations on daily, weekly, monthly or even yearly averaged time scales. Unfortunately, climate simulations using monthly or annually averaged (aggregated) simulations fail to consider high-intensity precipitation events of relatively short duration (Allan and Soden, 2008), and as such may severely underestimate groundwater recharge rates (Portmann et al., 2013; Wada et al., 2014).

While many methods exist for calculating recharge (e.g., Ngatcha et al., 2007; Scanlon et al., 2002), one common approach is to model variably saturated flow processes in the near-surface to partition precipitation into runoff, evaporation, root water uptake and deep drainage, and hence recharge (Assefa and Woodbury, 2013; Jiménez-Martinez et al., 2009; Leterme et al., 2012). Accurate modeling of vadose zone flow processes and recharge very much depends on having reliable weather data, including their temporal resolution such as daily versus monthly averaged data. Using high-resolution meteorological data is important for transient simulations, especially for 
climates having high precipitation rates but also long periods without much rain. In an earlier study (Batalha et al., 2012) we showed that using monthly averaged daily precipitation and evapotranspiration data can produce very different results for recharge as compared to using data having a daily resolution. This occurs since net infiltration, and hence recharge, is very much dependent upon the intensity of short-term rainfall events, as well as the local soil hydraulic properties. On the other hand, the more regular availability of water near the soil surface when precipitation and evaporation or evapotranspiration rates are averaged over relatively long time periods, will lead to less deep penetration of moisture and higher calculated evaporation rates, as compared to transient simulations involving precipitation and evapotranspiration patterns recorded over time periods of days, hours, or even minutes.

Several previous studies have shown the effects of temporal averaging on near-surface flow water flow and contaminant transport processes. For example, Wang et al. (2009) conducted a series of flow and transport simulations with daily data of a typical semi-arid region subject to considerable temporal variability in precipitation. They concluded that reliance on annual meteorological data, as done routinely for contaminant transport simulations, can significantly underestimate the downward migration of contaminants. Predictive errors stemming from the use of annual data increased considerably with time and were more pronounced for very permeable soils that allow water to penetrate much deeper during single rainfall events. Saifadeen and Gladnyeva (2012) similarly inferred that averaging moisture input over larger time periods will lead to underestimates of the center of mass migration, especially for more permeable (coarse-textured) soils. Related contaminant transport examples for different water inflow conditions, with some including steady-state flow conditions, are provided by Marshall et al. (2000), Kuntz and Grathwohl (2009), Harman et al. (2011), Vero et al. (2014) and Yin et al. (2015). In another study relating precipitation and recharge based on monthly and annual averages for groundwater modeling, Jyrkama et al. (2002) concluded that on a monthly basis, precipitation and recharge rates exhibited little correlation due to the delay caused by water percolating through the unsaturated zone.

The various studies above indicate that calculations of water flow into and through the vadose zone may depend very much upon temporal averaging of available meteorological data. Unfortunately, hourly or even daily data are often unavailable from weather stations, while only monthly- or yearly-average data may be present. The overall goal of our study was to find out how different ways of temporally averaging meteorological data would affect infiltration and groundwater recharge processes. Specific objectives were to investigate differences in predicted recharge rates resulting from hourly, daily, weekly, monthly and yearly averaged meteorological data from three sites in Brazil having different climatological conditions: a tropical savanna (the Cerrado), a humid subtropical area (the temperate southern part of Brazil), and a very wet tropical area (Amazonia). In our current analysis we did not consider any land use effects by ignoring root water uptake. The analysis hence is limited to evaporation processes from bare soils.

\section{SIMULATION METHODOLOGY}

Various numerical approaches may be used to estimate groundwater recharge (Assefa and Woodbury, 2013; Jyrkama and Sykes, 2007). In this study we evaluated the different temporal scaling effects on groundwater recharge using the HYDRUS 1-D software package of Šimůnek et al. (2013,
2016), which has been previously used in several other recharge studies (e.g., Assefa and Woodbury, 2013; Jiménez-Martinez et al., 2009; Leterme et al., 2012; Neto et al., 2016). Simulations were carried out for a 2-m deep unsaturated soil profile subject to transient meteorological conditions involving precipitation, evaporation and possible runoff. Preliminary calculations, not further shown here, indicated that a soil profile of $2 \mathrm{~m}$ was sufficient to estimate deep drainage, and hence recharge. Simulations of mean annual recharge using a 4-m deep profile differed by at most $5 \%$ for the most extreme situation when a relatively fine-texture soil was considered.

One-dimensional water flow in the soil profile can be represented using the classical Richards equation as follows

$$
\frac{\partial \theta(h)}{\partial t}=\frac{\partial}{\partial x}\left[K(h)\left(\frac{\partial h}{\partial x}-1\right)\right]
$$

where $h$ is the soil water pressure head [L], $\theta$ is the volumetric water content $\left[\mathrm{L}^{3} \mathrm{~L}^{-3}\right], t$ is time $[\mathrm{T}], x$ is the spatial coordinate (positive downwards) [L], and $K$ is the unsaturated hydraulic conductivity $\left[\mathrm{LT}^{-1}\right]$. The soil hydraulic relationships $\theta(h)$ and $K(h)$ in Eq. (1) were described using the constitutive relationships of van Genuchten (1980):

$$
\begin{aligned}
& S_{e}(h)=\frac{\theta(h)-\theta_{r}}{\theta_{s}-\theta_{r}}=\left\{\begin{array}{cc}
\left(1+|\alpha h|^{n}\right)^{-m} & h<0 \\
1 & h \geq 0
\end{array}\right. \\
& K(h)=K_{s} S_{e}^{l}\left[1-\left(1-S_{e}^{1 / m}\right)^{m}\right]^{2}
\end{aligned}
$$

where $S_{e}$ is effective saturation [-], $\theta_{r}$ and $\theta_{\mathrm{s}}$ are the residual and saturated volumetric water contents, respectively $\left[\mathrm{L}^{3} \mathrm{~L}^{-3}\right]$, $K_{s}$ is the saturated hydraulic conductivity $\left[\mathrm{LT}^{-1}\right], \alpha\left[\mathrm{L}^{-1}\right], n>1$ $[-]$ and $l[-]$ are shape factors, and $m=1-1 / n[-]$. Following van Genuchten (1980), the pore-connectivity parameter $l$ was fixed at a value of 0.5 .

The 2-m deep soil profile was discretized into a 201-node finite element mesh with variably-sized elements (smaller values near the soil surface) to facilitate numerical convergence during the calculations. Atmospheric boundary conditions were considered at the soil surface to enable prescribed flux or pressure head conditions depending upon prevailing meteorological conditions (Šimůnek et al., 2013). The boundary fluxes and heads were limited by given precipitation and potential evaporation fluxes in combination with specific parameters to restrict boundary pressure heads to remain above prescribed minima (in our study $-100,000 \mathrm{~cm}$ ) during evaporation, and below certain maximum values (e.g., $0 \mathrm{~cm}$ ) during precipitation events (surface runoff may then occur). Several simulations also considered the situation where ponding of up to $2.5 \mathrm{~cm}$ could occur. This situation may be more realistic for relative flat terrains with a low-permeability surface horizon. The lower boundary condition of the flow domain was set as free drainage $(\partial h / \partial x=$ $0)$. We note that HYDRUS-1D uses a self-adjusting timestepping scheme for numerical solution of the Richards equation (Šimůnek et al., 2013). This is important since numerical time steps will be reduced automatically to sometimes seconds or less to correctly simulate high-intensity infiltration rates in relatively dry soils, while remaining consistent with the hourly or daily input data. 


\section{METEOROLOGICAL DATA}

Data from three sites in Brazil (Fig. 1) representing different climatic regions were used for the groundwater recharge calculations. The sites represented the following regions (from driest to wettest site): a tropical savanna (the Cerrado region), a humid subtropical area (the temperate South of Brazil), and a tropical area (Amazonia). Average annual rainfall rates for the three sites were about 1500,1600 and $2500 \mathrm{~mm}$, respectively. Figure 2 shows daily rainfall data for the three weather stations. While annual rainfall in the Cerrado is still relatively high (about $1500 \mathrm{~mm} / \mathrm{yr}$ ), rainfall is not distributed evenly over the year. The Cerrado is characterized by summers (DecemberMarch) with intense rainfall, and very dry winters. The average monthly temperature variation is only about $4.4^{\circ} \mathrm{C}$ (even though daily temperatures vary about $12^{\circ} \mathrm{C}$ ). Meteorological data from the Cerrado were taken from Paracatu Station located at $17.25 \mathrm{~S}, 46.88 \mathrm{~W}$, and having an altitude of $625 \mathrm{~m}$ above mean sea level (a.s.1.).

The subtropical site in southern Brazil (further referred to as the Temperate site) has a warm but relatively temperate climate. As compared to the Cerrado, precipitation at this site is not much higher (about $1600 \mathrm{~mm} / \mathrm{y}$ ) but distributed far more evenly over the year. Even the driest month (July) shows considerable precipitation. Mean temperature varies by $8.8^{\circ} \mathrm{C}$ throughout the year, with daily variations being about $10^{\circ} \mathrm{C}$. Meteorological data for this area were taken from the Urussanga weather station $(28.51 \mathrm{~S}, 49.17 \mathrm{~W})$ at an altitude of $48.2 \mathrm{~m}$ a.s.l. The third site, located in the Amazonia, is characterized by significant rainfall (about $2500 \mathrm{~mm} / \mathrm{y}$ ), and a very short "dry" period in August. Temperatures do not vary much along the year (only about $1.3^{\circ} \mathrm{C}$ ), while daily variations are relatively small also (about $8^{\circ} \mathrm{C}$ ).

Meteorological data for the three sites for a five-year period (2008 through 2012) were downloaded from the Brazilian National Meteorological Institute website (INMET, 2015). The data included daily precipitation $(\mathrm{mm})$, maximum and minimum temperatures $\left({ }^{\circ} \mathrm{C}\right)$, wind speed $\left(\mathrm{km} \mathrm{d}^{-1}\right)$ at $200 \mathrm{~cm}$ above the land surface, air humidity (\%) and daily sunshine hours. The data were used to calculate daily potential evaporation rates using the Penman-Monteith combination equation (Allen et al., 1998):

$$
E_{p}=\frac{0.408 \Delta\left(R_{n}-G\right)+\gamma \frac{900}{T+273} U_{2}\left(e_{a}-e_{d}\right)}{\Delta+\gamma\left(1+0.34 U_{2}\right)}
$$

in which $\Delta$ is the slope of the saturation vapor pressure temperature curve $\left(\mathrm{kPa}^{\circ} \mathrm{C}^{-1}\right)$, and $\gamma$ the psychrometric constant $(\mathrm{kPa}$ ${ }^{\circ} \mathrm{C}^{-1}$ ) as follows:

$$
\begin{aligned}
& \Delta=\frac{4098 e_{a}}{(T+237.3)^{2}} \\
& \gamma=\frac{P c_{p}}{\varepsilon \lambda} * 10^{-3}=0.00163 \frac{P}{\lambda}
\end{aligned}
$$

In the equations above, $E_{p}$ is the potential evaporation rate $\left[\mathrm{mm} \mathrm{d}^{-1}\right], R_{n}$ is net radiation at the soil surface $\left[\mathrm{MJ} \mathrm{m}^{-2} \mathrm{~d}^{-1}\right], G$ is the soil heat flux density [ $\left.\mathrm{MJ} \mathrm{m}^{-2} \mathrm{~d}^{-1}\right], T$ is the average daily air temperature $\left[{ }^{\circ} \mathrm{C}\right] ; U_{2}$ is the wind speed at $2 \mathrm{~m}$ height $\left[\mathrm{m} \mathrm{s}^{-1}\right], e_{a}$ is the saturation vapor pressure at temperature $T[\mathrm{kPa}], e_{d}$ is actual vapor pressure $[\mathrm{kPa}], P$ is atmospheric pressure $[\mathrm{kPa}], c_{p}$ is the specific heat of moist air (assumed to be $1.013 \mathrm{~kJ}$ $\left.\mathrm{kg}^{-1}{ }^{\circ} \mathrm{C}^{-1}\right), \varepsilon$ is the ratio of the molecular weights of water vapor and dry air (0.622), and $\lambda$ is the latent heat of vaporization [MJ $\left.\mathrm{kg}^{-1}\right]$. We emphasize that Eqs. (4)-(6) were used to calculate potential evaporation rates. Actual evaporation (and infiltration) rates are limited by the soil to produce (or accept) the potential surface fluxes as modeled using the atmospheric boundary conditions of HYDRUS-1D (Šimůnek et al., 2013).

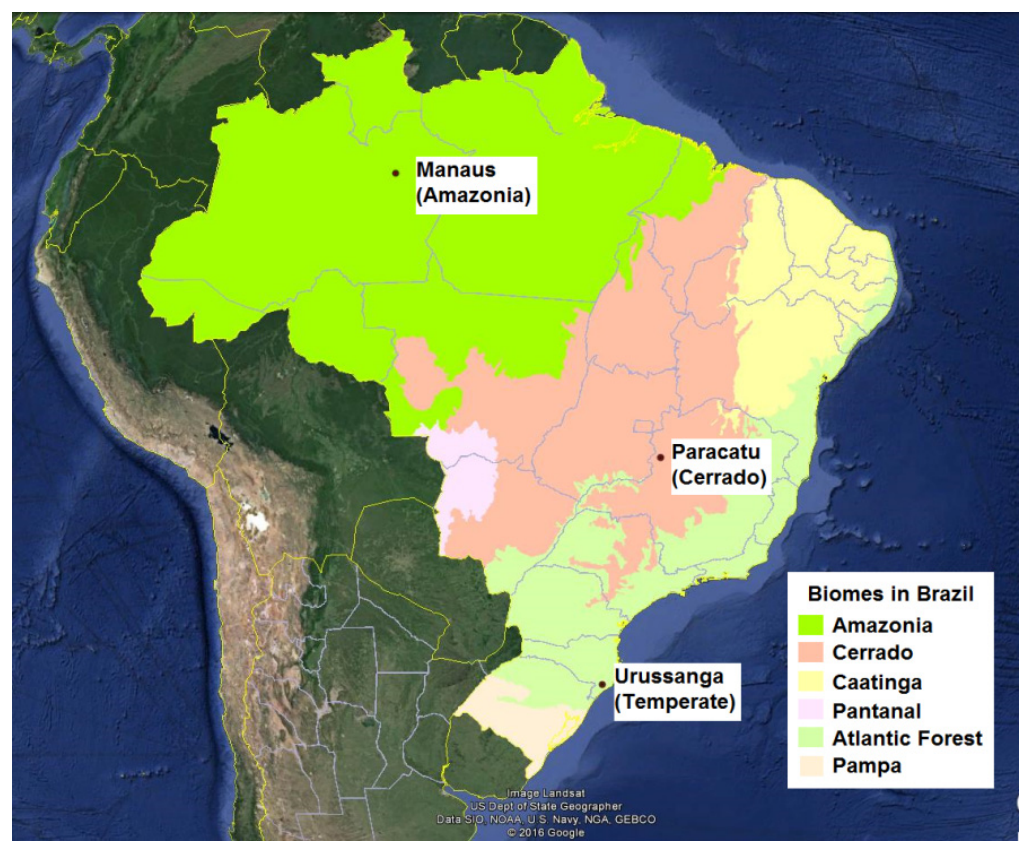

Fig. 1. Location of the three meteorological sites in Brazil (adapted from an image mask from the IBGE site (ftp://geoftp.ibge.gov.br/mapas_interativos/) using Google Earth Software). 


\section{Precipitation}
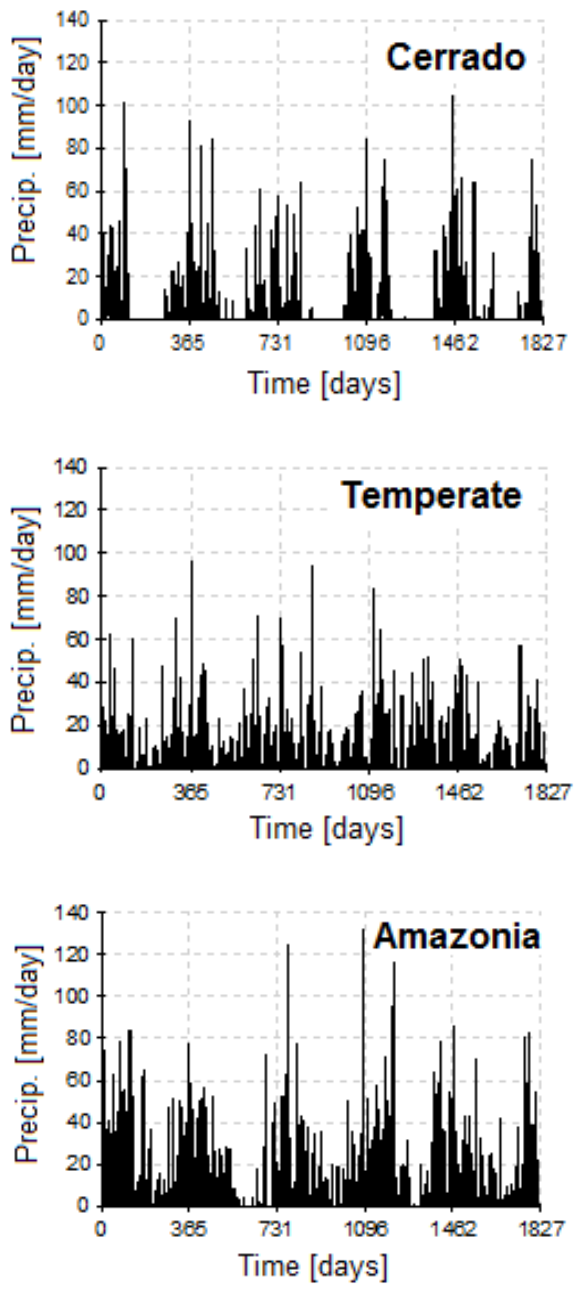

Potential Evaporation
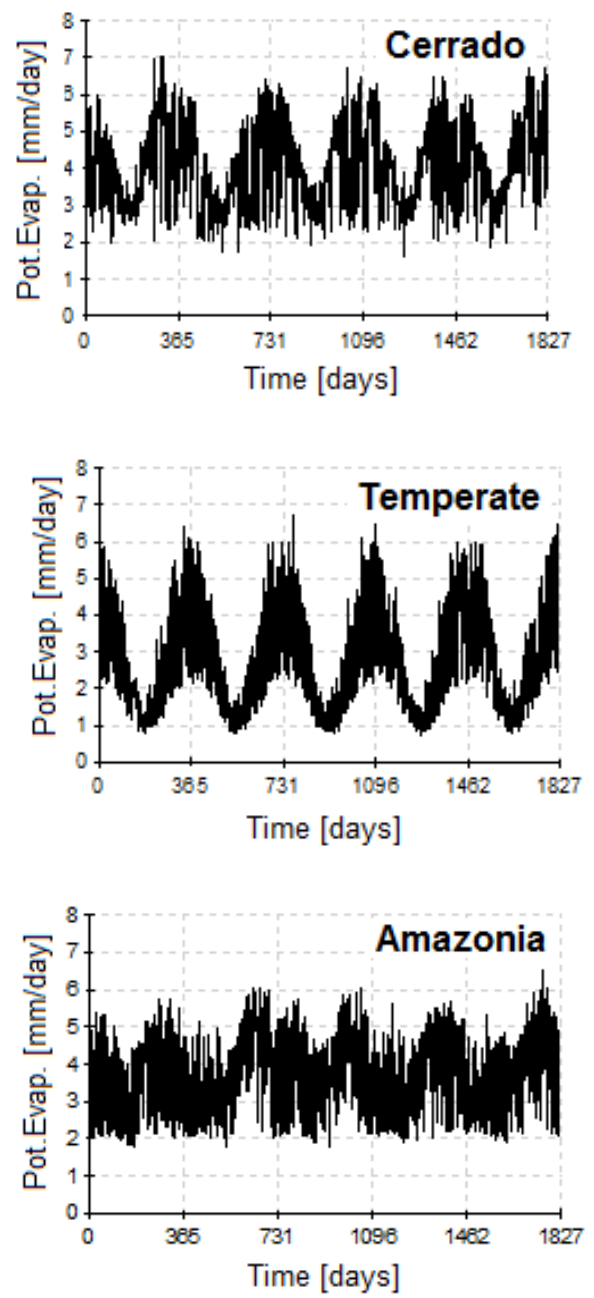

Fig. 2. Observed daily precipitation and calculated daily potential evaporation rates for the Cerrado, Temperate and Amazonia sites.

Figure 2 shows daily precipitation and calculated potential evaporation rates for the Cerrado, Temperate and Amazonia sites. The plots show that the Cerrado has well-defined seasons with precipitation concentrated mostly in the Brazilian summer months, while precipitation at the Amazonia site and especially the Temperate site are distributed much more evenly over the year. By comparison, potential evaporation is least variable during the year at the Amazonia site, ranging from 2 to about 6 $\mathrm{mm} /$ day, and most variable in the Temperate region (ranging between 2.5 and $6 \mathrm{~mm} / \mathrm{d}$ in the summer and between 1 and 1.5 $\mathrm{mm} / \mathrm{d}$ in the winter months). The precipitation data in Figure 2 represent daily rates (daily totals) during the 5-year study period. We also carried out recharge calculations using hourly input values of precipitation and evaporation. Unfortunately, hourly data are generally not collected at meteorological stations. For our hourly recharge calculations we used precipitation data from Criciuma, which is located about $30 \mathrm{~km}$ from the Temperate (South) weather station in Urussanga and has very similar climatological conditions as those in Criciuma. The hourly data were obtained in 2008 by Soares et al. (2012) for an acid mine drainage project in the area. Since only one year of hourly precipitation data were available, the 2008 data were scaled up or down in such a way that the daily values for the years 20092012 were respected. For the 5-year study we obtained in this way close to 44,000 hourly precipitation data entries.
We also generated hourly potential evaporation data corresponding to the hourly precipitation data. One possible approach to generate these is to use hourly time steps in a Penman-Monteith type procedure as advocated by ASCE (2005). Since our study already used daily potential evaporation rates, we downscaled the daily rates to hourly values in a manner consistent with the daily total values. The conversion was done in accordance with previous experimental studies of hourly evaporation and evapotranspiration rates by van Bavel (1966), van Bavel and Hillel (1976), and Katul and Parlange (1992), as well as with similar studies of diurnal patterns of other meteorological variables such as temperature (Ephrath et al., 1996; Kimball and Bellamy, 1986; Wann et al., 1985). The approach, as also programmed in the HYDRUS-1D code, assumes that the daily evaporation rate (the daily total) can be distributed sinusoidally over the day into hourly rates such that they represent about $12 \%$ of the daily total between $0-6$ am and between 18 $24 \mathrm{pm}$, and $88 \%$ during the remainder of the day (Šimůnek et al., 2013). Mathematically, the distribution over the day (24 h) for the potential evaporation rate is then described by

$E_{p}(t)=\left\{\begin{array}{lll}0.24 \overline{E_{p}} & (t<0.264 d & \text { or } t>0.736 d) \\ 2.75 \overline{E_{p}} \sin \left(\frac{2 \pi t}{24}-\frac{\pi}{2}\right) & 0.264 d \leq t \leq 0.736 d)\end{array}\right.$ 
where $\overline{E_{p}}$ is the daily value of the potential evaporation rate.

The procedures above allowed us to define daily and hourly meteorological data for the 5-year recharge calculations. Our temporal averaging procedure considered at first daily precipitation and temperatures as well as later also all parameters needed for the Penman-Monteith equation yielding daily evaporation rates. Once daily evaporation and precipitation data were available for the different sites, the data were averaged over time using the expression:

$$
M P=\frac{1}{n} \sum_{i=1}^{n} m p_{i} \quad \begin{cases}n=7 & \text { for weekly approach } \\ n=30 & (28,29 \text { or } 31) \text { for monthly } \\ n=365 & (366) \text { for yearly }\end{cases}
$$

where $m p_{i}$ represents the available daily meteorological data (i.e., precipitation or evaporation), $n$ is the period of temporal averaging, and $M P$ is the average daily rate of the meteorological parameter over the time period being considered.

To assess the effect of soil texture on recharge as calculated using the temporally average data, we decided to carry out the simulations for three different soil types covering relatively coarse- to fine-textured soils: a loamy sand, a loam and a clay loam. Soil hydraulic parameters for these soils were defined using pedotransfer functions derived by Carsel and Parrish (1988). The parameters used are presented in Table 1. We used these parameters to define initial pressure head conditions for each simulation that were consistent with the long-term average recharge rates obtained for the particular meteorological conditions.

Table 1. Soil hydraulic parameters in Eqs. (1) and (2) for the three soils used in the simulations.

\begin{tabular}{lccccc}
\hline $\begin{array}{l}\text { Soil } \\
\text { Texture }\end{array}$ & $\begin{array}{c}\theta_{r} \\
(-)\end{array}$ & $\begin{array}{c}\theta_{s} \\
(-)\end{array}$ & $\begin{array}{c}\alpha \\
\left(\mathrm{cm}^{-1}\right)\end{array}$ & $\begin{array}{c}n \\
(-)\end{array}$ & $\begin{array}{c}K_{s} \\
\left(\mathrm{~cm} \mathrm{~d}^{-1}\right)\end{array}$ \\
\hline Loamy sand & 0.057 & 0.410 & 0.124 & 2.28 & 350. \\
Loam & 0.078 & 0.430 & 0.036 & 1.56 & 25.0 \\
Clay loam & 0.095 & 0.410 & 0.019 & 1.31 & 6.24 \\
\hline
\end{tabular}

\section{RESULTS AND DISCUSSION}

In this section we compare results of the recharge calculations for the temporal averaging schemes involving daily, weekly, monthly and yearly averaged meteorological data. Figure 3 shows that rapid temporal changes in the recharge rate at the Cerrado site occur when daily averaged meteorological data are used as compared to monthly averaged values, while the overall patterns are generally identical (values of the daily and monthly recharge rates are shown on the left-hand side yaxis). However, the pattern of daily recharge rates when using yearly averaged data (values shown on the right-hand side axis) is significantly different from those for the daily and monthly averaged meteorological data.

Figure 4 shows box-and-whisker diagrams (Chambers et al., 1983) of the daily recharge rates obtained for the Cerrado site using daily, monthly, and yearly averaged meteorological data. The plots include the minimum, first quartile $\left(25^{\text {th }}\right.$ percentile $)$, median, third quartile ( $75^{\text {th }}$ percentile), and maximum quartiles, as well as the upper and lower whiskers representing the $+/-1.5$ interquartile ranges between the first and third quartiles of the corresponding upper and lower quartiles. The statistical parameters are also summarized in Table 2. The data show that, notwithstanding the differences between the minimum and maximum recharge values obtained with the daily and monthly

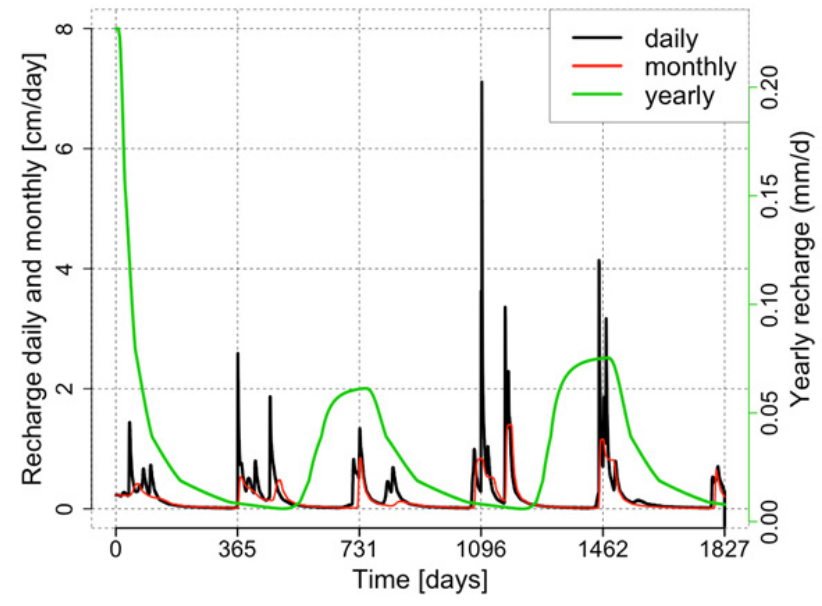

Fig. 3. Time series of groundwater recharge rates obtained using daily, monthly, and yearly averaged meteorological data from the Cerrado site. Please note the different scales for the daily and monthly data (left side) and the yearly data (right side).

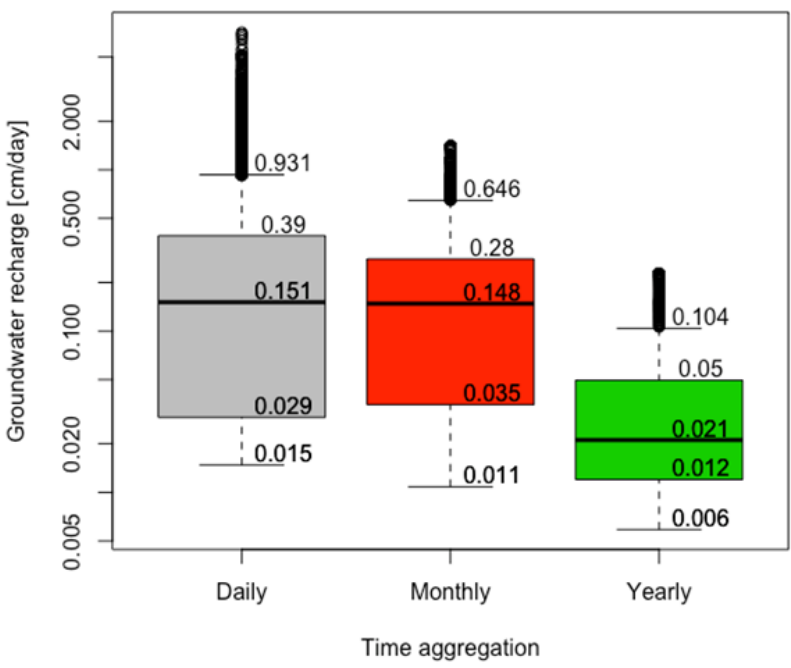

Fig. 4. Box-and-whisker plots and statistical parameters of groundwater recharge rates obtained using daily, monthly, and yearly averaged meteorological data from the Cerrado site, as calculated using the time series shown in Figure 3.

Table 2. Statistical parameters of recharge rates at the Cerrado site as obtained with daily, monthly, and yearly averaged meteorological data.

\begin{tabular}{lrrr}
\hline & Daily & Monthly & Yearly \\
\hline Lower hinge & -0.288 & 0.0108 & 0.00588 \\
$25 \%$ & 0.0268 & 0.0350 & 0.0120 \\
Median & 0.148 & 0.148 & 0.0211 \\
$75 \%$ & 0.414 & 0.280 & 0.0496 \\
Upper hinge & 0.994 & 0.646 & 0.104 \\
\hline
\end{tabular}

averaged input data, the median values are the same $(0.148$ $\mathrm{cm} / \mathrm{d}$ ) and much larger than the median of the recharge rate obtained with yearly averaged data $(0.021 \mathrm{~cm} / \mathrm{d})$. Note that the vertical axis in Figure 4 is given on a log scale to demonstrate to more clearly visualize the range of variations in recharge for the three types of input data.

To quantitatively assess differences in the calculated recharge rates using daily, monthly, and yearly averaging of the weather data, we also applied a Kolmogorov-Smirnov (KS) goodness-of-fit test. The nonparametric KS test is used to 


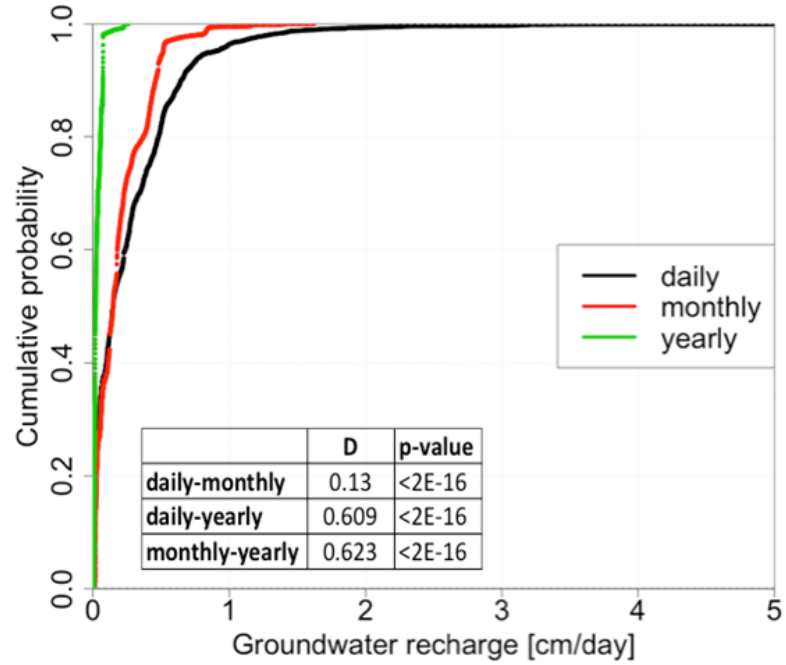

Fig. 5. Cumulative distributions of groundwater recharge rates obtained using daily, monthly, and yearly averaged meteorological data from the Cerrado site (the table shows results of the Kolmogorov-Smirnov test).

determine the probability that a given dataset is drawn from the same parent population as a second dataset (called the twosample KS test; Marsaglia et al., 2003). The KS statistics are measures of the supremum, being the greatest distance between the empirical cumulative distribution functions (CDFs) of the datasets. The CDFs, along with results of calculations, are shown in Figure 5. Based on the $D$ statistical measure of the discrepancy between the CDFs, we reject the hypothesis that the distributions are similar. This can be seen from the table entries in Figure 4, which show that the difference between the daily and monthly recharge rates is far less than the difference between daily and yearly values, as well as between the monthly and yearly recharge estimates.

Calculated daily recharge rates for the three ways of temporal averaging are shown in Figures 6 and 7. Figure 6 demonstrates differences in the temporal distributions of groundwater recharge caused by different patterns of precipitation, while Figure 7 depicts the corresponding box-and-whiskers plots along with the statistical parameters for recharge at the three sites. As expected from the climatic conditions at the three sites (Fig. 2), the lowest values of recharge are at the Cerrado site (the negative lower value indicates that evaporation actually slightly exceeded infiltration), and the highest values are at the Amazonia site.

Figure 8 compares results for the three soil types at each site. Each plot shows for the same period of averaging the calculated annual recharge rates. In all cases, the highest recharge rates occurred when using daily averaged data, while the yearly averaged data always produced the lowest values. The plots show that differences between the higher and lower values can be very significant. The most extreme situation occurred for the Cerrado, where daily averaged data generated up to 9 times higher annual average recharge rates than when yearly averaged data were used. The main reason relates to the irregular distribution of the meteorological data, especially precipitation, over the year (Fig. 2). The more uneven the precipitation distribution, the higher the difference in calculated recharge rates. When precipitation is confined to only a short period of the year, more water penetrates below layers near the soil surface from which upward flow and evaporation is still possible. This effect is clearly shown when comparing results for the Cerrado with those for the Temperate and Amazonia sites. Even though

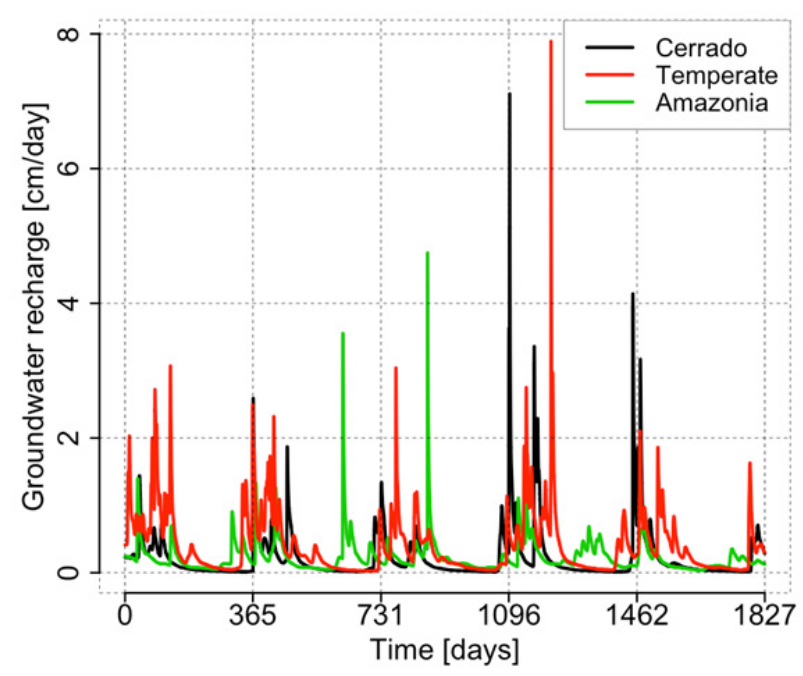

Fig. 6. Comparison of daily groundwater recharge for three sites, demonstrating different temporal seasonal patterns, depending on meteorological conditions at the sites.

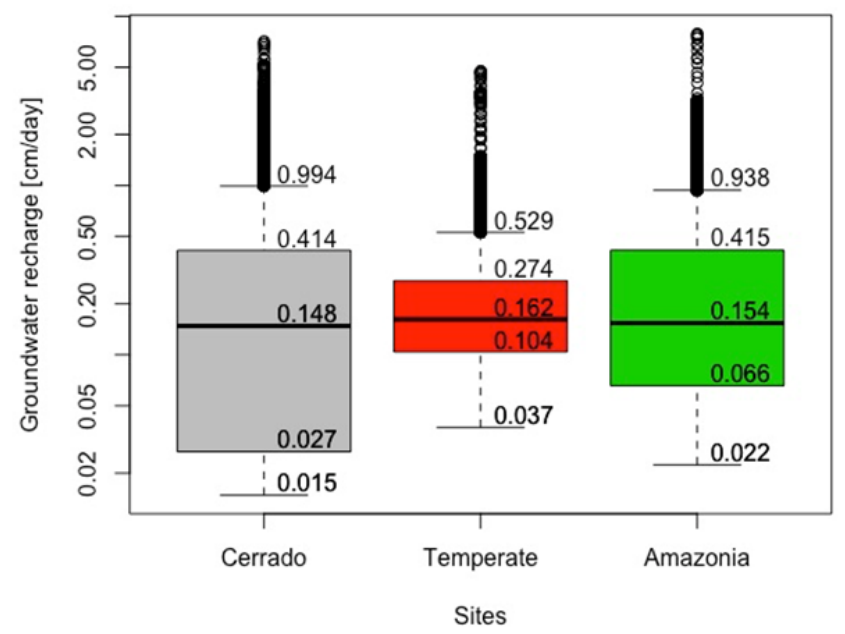

Fig. 7. Box-and-whisker plots and statistical parameters of groundwater recharge rates obtained using daily, monthly, and yearly averaged meteorological data from the Cerrado, Temperate and Amazonia sites, as calculated using the time series shown in Figure 6.

the annual precipitation rate at the Temperate site $(1600 \mathrm{~mm})$ was only slightly larger than at the Cerrado site $(1500 \mathrm{~mm})$, the differences in calculated recharge rates between the daily and annually averaged data were much smaller for the Temperate site. The same occurs for the Amazonia site, even with its much larger annual precipitation rates. Using daily averaging, the recharge rates can still be 25 to $82 \%$ higher than for yearly averaging, depending upon soil type.

Figure 8 further shows that the effect of soil texture on the calculations can be quite important when the temporal averaging period is relatively short (daily or weekly). Coarser soils tend to produce 30 to $40 \%$ more recharge as long as the hydraulic conductivity is relatively high to allow most of the infiltrated water to move rapidly below the zone of influence for upward flow. On the other hand, fine-textured soils may act as buffers by keeping moisture closer to the surface to enable subsequently upward flow and evaporation. This occurs especially when the hydraulic conductivity of the surface layer is lower than the precipitation rate, in which case fine-textured soils facilitate runoff and thus further diminish infiltration and recharge. 

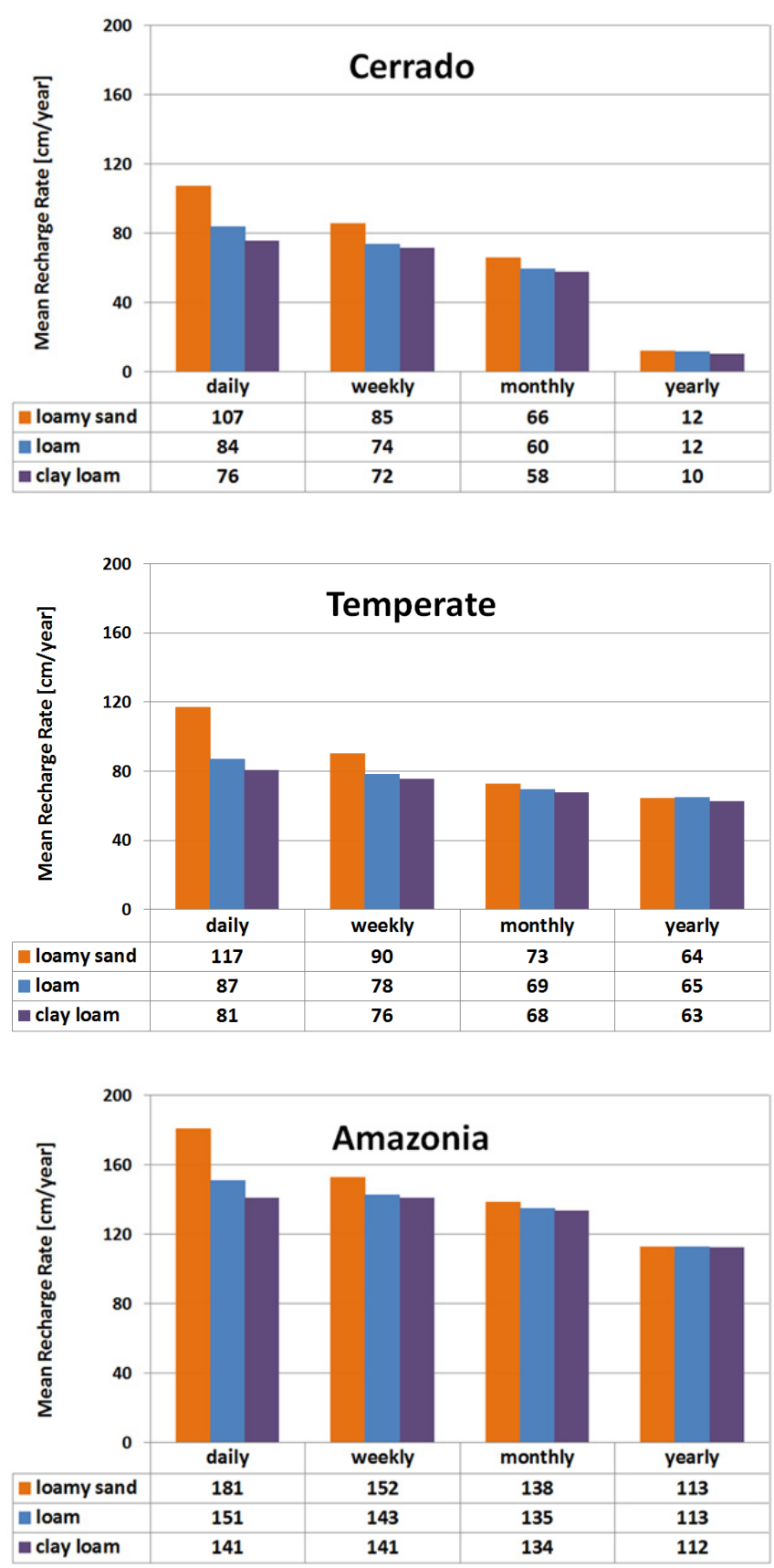

Fig. 8. Calculated average annual recharge rates at the Cerrado (top), Temperate (middle) and Amazonia (bottom) sites as obtained using daily, monthly, and yearly averaged meteorological data.

Calculated groundwater recharge rates as a percentage of rainfall for the same period (2008 through 2012) at the different sites are presented in Table 3. Estimated recharge rates calculated in this study using the daily averaged weather data were surprisingly independent of location, ranging mostly between $50 \%$ for the fine-textured clay loam soil, to about $75 \%$ for the more coarse-textured loamy sand. Values for the weekly, monthly and yearly averaged data on average were always lower, especially when using the yearly data of the Cerrado, where recharge became less than $8 \%$ of annual precipitation, irrespective of soil type. The Cerrado situation is quite similar to what was observed in (semi-) arid sites for contaminant transport by Wang et al. (2009) and Harman et al. (2011).
Table 3. Calculated recharge rates as a percentage of rainfall at the Brazilian Cerrado, Temperate and Amazonia sites.

\begin{tabular}{|c|c|c|c|}
\hline Averaging & $\begin{array}{c}\text { Loamy } \\
\text { sand }\end{array}$ & Loam & $\begin{array}{l}\text { Clay } \\
\text { loam }\end{array}$ \\
\hline \multicolumn{4}{|c|}{--------- Cerrado --------- } \\
\hline Daily & 72 & 56 & 51 \\
\hline Weekly & 58 & 50 & 48 \\
\hline Monthly & 44 & 40 & 39 \\
\hline Yearly & 8 & 8 & 7 \\
\hline \multicolumn{4}{|c|}{---------- Temperate ---------- } \\
\hline Hourly & 76 & $47 / 51^{*}$ & $22 / 46^{*}$ \\
\hline Daily & 72 & 54 & 50 \\
\hline Weekly & 56 & 48 & 47 \\
\hline Monthly & 45 & 43 & 42 \\
\hline Yearly & 39 & 40 & 39 \\
\hline \multicolumn{4}{|c|}{--------- Amazonia ---------- } \\
\hline Daily & 73 & 61 & 57 \\
\hline Weekly & 62 & 58 & 57 \\
\hline Monthly & 56 & 55 & 54 \\
\hline Yearly & 46 & 46 & 45 \\
\hline
\end{tabular}

*The first value refers to a runoff and the second to a ponding boundary condition

Those studies showed that daily averaged calculations predicted significant contaminant transport, while little transport occurred when annually averaged precipitation data were considered.

The data in Table 3 indicate recharge always will be underestimated when monthly and, especially, yearly averaged meteorological data are used. The hourly values for the Temperate site generated much more variation among soil type when runoff was considered. The values in Table 3 (between 40 and $75 \%$, except for the Cerrado) are well within the range of literature values documented by Kim and Jackson (2012) for unvegetated surfaces. They also correspond to or exceed the upper limits of annual values for vegetated surfaces inventories by Kim and Jackson (2012) and determined by Santoni et al. (2010) and Assefa and Woodbury (2013), among others. As noted by Assefa and Woodbury (2013) and confirmed by our results, recharge rates can be very variable in time (see also Fig. 6) depending upon transient weather conditions and soil type. Still, we acknowledge that our values should be higher, in part since we did not consider any root water uptake in this study.

The plots and data in Figure 8 indicate that cumulative recharge is always lower when considering yearly averaged data. Similar calculations that include also results for the hourly averaged precipitation and evaporation data are presented in Figure 9 for the Temperate site. The simulations show that runoff is now becoming also an important term, especially for the fine-textured (clay loam) soils. In that case the hourly precipitation rates can become larger than the saturated hydraulic conductivity $\left(K_{s}\right)$, leading to runoff when an atmospheric boundary condition with possible runoff is considered (Figure 8 , top plots). It is also possible to allow water to pond on the surface by assuming the presence of a relatively flat soil surface, in which case little or no runoff may occur. The simulations shown in Figure 8 (bottom) were obtained for the intermediate situation where runoff would occur only when reaching a ponding depth of more than $2.5 \mathrm{~cm}$ on the soil surface. Results for the hourly data in that case are now very close to those for the daily meteorological data. The results in Figure 10 indicate that the runoff component can be important and with standard numerical calculations will show up mostly when hourly averaged data are used, and then only for medium- and especially fine-textured soils. No difference between the hourly 


\section{Temperate}
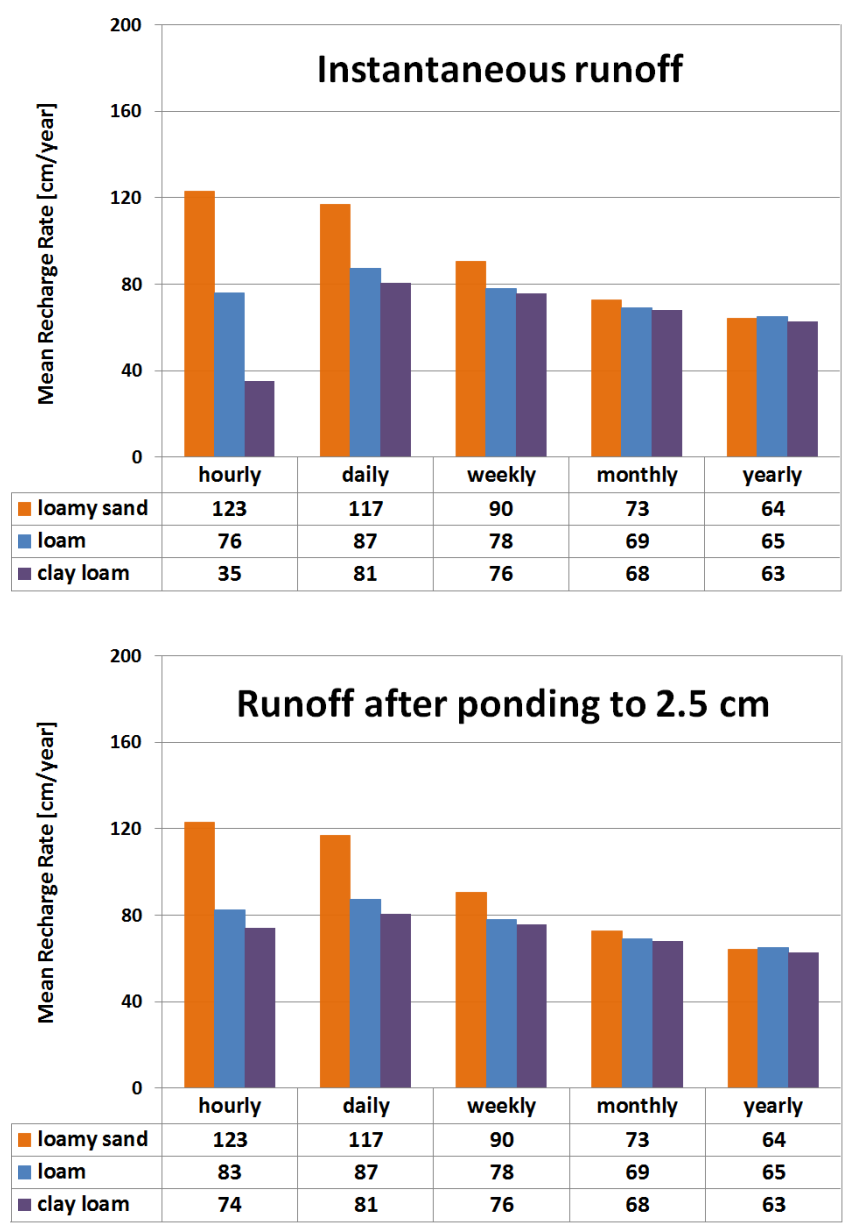

Fig. 9. Calculated average annual recharge rates for the Temperate site as obtained using hourly, daily, weekly and monthly averaged weather data assuming atmospheric boundary conditions with instantaneous runoff (top plot) and with runoff occurring only after reaching a ponding level of $2.5 \mathrm{~cm}$.

and daily calculations occurred for loamy sand since the hourly averaged precipitation rates never exceeded the saturated hydraulic conductivity of $350 \mathrm{~cm} /$ day. On the other hand, when ponding is considered, the results for the hourly averaged data tend to closely approximate results for the daily averaged data also for the fine-textured soil.

The important effect of possible runoff is further demonstrated in Figure 10, which shows cumulative recharge during 5 years for both the hourly averaged data (dotted lines) and the daily averaged data (continuous lines) for both the loam and clay loam soils. Results are for the cases with instantaneous runoff (dotted line) and runoff after ponding to $2.5 \mathrm{~cm}$ (dashed line). Calculations show that hourly averaged data lead to far less infiltration, and hence lower recharge rates, for the clay loam soil.

\section{CONCLUDING REMARKS}

In this study we evaluated the effects of temporal averaging of meteorological data on calculated groundwater recharge rates for three sites in Brazil having very different climatological conditions. Calculations showed that the use of temporally averaged meteorological data can lead to very different results in the recharge calculations, decreasing from daily, weekly,
Temperate
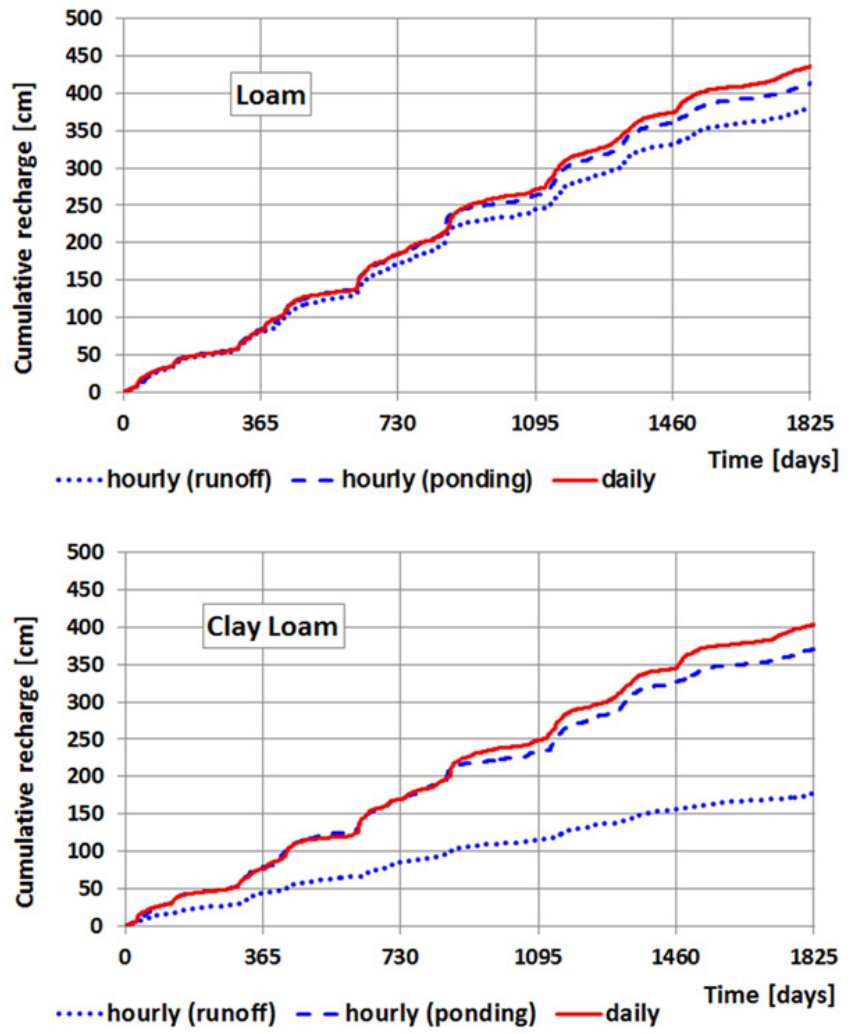

Fig. 10. HYDRUS-1D calculated cumulative recharge rates obtained with hourly and daily data for the loam (top) and clay loam (bottom) soils with and without ponding.

monthly, to yearly averaged data, with the yearly average data always producing the lowest recharge rates. Results were especially sensitive to averaging when applied to the Cerrado Region in Brazil where recharge rates using daily averaged data were up to 9 times the recharge rate for yearly averaged meteorological data. But the effects were also apparent for the Temperate and Amazonia sites where the differences ranged from 25 to $82 \%$. The important effects of averaging at the Cerrado site were related to the highly uneven rainfall distribution over the year involving distinct wet and dry seasons. Yearly averaging may then even lead to near-zero recharge rates in certain time periods, with concomitant significant underestimates of the actual recharge rates.

While rainfall and its temporal distribution in time are important determinants for recharge, another factor is soil type. When averaging weather data (and hence infiltration) over longer periods of time, infiltrated water will fail to reach soil depths below the influence of evaporation, even in coarsetextured soils. The soils then do not dry out very much, thus causing evaporation rates to be overestimated, and recharge underestimated, in some cases by up to $50 \%$. By comparison, fine-textured soils can better regulate near-surface soil moisture conditions during high precipitation events, leading to recharge rates that are less dependent upon time averaging (daily to monthly values), except for the yearly averaged data.

Another important effect of temporal averaging of weather data is its effect on runoff, which relates to the amount of water not infiltrated into a soil during a rainfall event. Infiltration rates during a particular precipitation event ultimately depend on the saturated hydraulic conductivity, $K_{s}$. Runoff will occur when the precipitation rate is higher than $K_{s}$ for an appreciable 
time period depending on the initial soil moisture conditions. Long-term averaging will smooth available precipitation data to rates that will always be less than $K_{s}$, especially for weekly, monthly and yearly averaged data. Even daily averaged data seldom produce runoff, unless very fine-textured soils are present. Lack of runoff will then actually increase local recharge rates. This is why in actuality hourly calculations should be used for fine-textured soils, subject of course to data availability. Differences, however, will become less significant if ponding will occur in relatively flat areas, thus minimizing runoff. Overall results of this study indicate that daily averaged meteorological data should be used as much as possible, while yearly averaged data should be avoided as much as possible.

We emphasize that the current study is limited to simulations of vadose zone flow and evaporation, without directly modeling of root water uptake, which would lead to reduced recharge rates. We plan to document the additional effects of land use in a separate document. We further acknowledge that other processes such as especially preferential flow in a heterogeneous soil profile may also modify recharge rates, especially during high-precipitation events in conjunction with surface ponding.

Acknowledgements. BF's part of this study was supported by NGEE-Tropics, funded by the U.S. Department of Energy, Office of Science, Office of Biological and Environmental Research, and Office of Advanced Scientific Computing, under the DOE Contract No. DE-AC02-05CH11231.

\section{REFERENCES}

Aeschbach-Hertig, W., Gleeson, T., 2012. Regional strategies for the accelerating global problem of groundwater depletion. Nature Geosci., 5, 853-861.

Allan, R.P., Soden. B.J., 2008. Atmospheric warming and the amplification of precipitation extremes. Science, 321, 14811481.

Allan, P., Soden, B.J., John, V.O., Ingram, W., Good, P., 2010. Current changes in tropical precipitation. Environ. Res. Lett., 5, 025205, 7 p.

Allen R.G., Pereira, L.S., Raes, D., Smith, M., 1998. Crop Evapotranspiration; Guidelines for Computing Crop Water Requirements. FAO Irrigation and Drainage Paper 56. Food and Agriculture Organization of the United Nations, Rome, Italy.

ASCE, 2005. The ASCE Standardized Reference Evapotranspiration Equation. Environmental and Water Resources Institute of ASCE, Final Report. American Society of Civil Engineers, Reston, VA, USA.

Assefa, K.A., Woodbury, A.D., 2013. Transient, spatially varied groundwater recharge modeling. Water Resour. Res., 49, 4593-4606.

Batalha, M.S., Bezerra, C.R., Jacques, D., Barbosa, M.C., Pontedeiro, E.M., van Genuchten, M.Th., 2012. Multicomponent transport predictions of ${ }^{226} \mathrm{Ra}$ in soil following the use of phosphogypsum. In: Proc. 4th Int. Conf. on Engineering for Waste and Biomass Valorization, WASTENG, Porto, Portugal, 6 p.

Carsel R.F., Parrish. R.S., 1988. Developing joint probability distributions of soil water retention characteristics. Water Resour. Res., 4, 755-769.

Chambers, J.M., Cleveland, W.S., Kleiner, B., Tukey, P.A., 1983. Graphical Methods for Data Analysis. Wadsworth \& Brooks/Cole.

Ephrath, J.E., Goudriaan, J., Marani, A., 1996. Evaluation and calibration of three models for daily cycle of air temperature, radiation, wind speed and relative humidity by equations from daily characteristics. Agric. Syst., 51, 4, 377-393.

Gee, G.W., Hillel, D., 1988. Groundwater recharge in arid regions: Review and critique of estimation methods. Hydrol. Process., 2, 255-266. DOI: 10.1002/hyp.3360020306.

Gleeson, T., Befus, K.M., Jasechko, S., Luijendijk, E., Cardenas, M.B., 2015. The global volume and distribution of modern groundwater. Nature Geosci., 9, 161-167.

Gorelick, S.M., Zheng, C., 2015. Global change and the groundwater management challenge. Water Resour. Res., 51, 3031-3051, DOI: 10.1002/ 2014WR016825.

Harman, C.J., Rao, P.S.C., Basu, N.B., McGrath, G.S., Kumar, P., Sivapalan, M., 2011. Climate, soil, and vegetation controls on the temporal variability of vadose zone transport. Water Resour. Res., 47, W00J13

INMET, 2015. Instituto Nacional de Meteorologia, Ministério da Agricultura, Pecuária e Abastecimento $<$ http://www.inmet.gov.br/portal/index.php?r=bdmep/bdmep>, Brazil.

Jasechko, S., Taylor, R.G., 2015. Intensive rainfall recharges tropical groundwaters Environ. Res. Lett., 10, 124015.

Jimenez-Martinez, J., Skaggs, T.H., van Genuchten, M.Th., Candela, L., 2009. A root zone modelling approach to estimating groundwater recharge from irrigated areas. J. Hydrol., 367, 138-149.

Jyrkama, M.I., Sykes, J.F., 2007. The impact of climate change on spatially varying groundwater recharge in the grand river watershed (Ontario). J. Hydrol., 338, 237-250.

Jyrkama, M.I., Sykes, J.F., Normani, S.D., 2002. Recharge estimation for transient ground water modeling. Ground Water, 40, 638-648.

Katul, G.G., Parlange, M.B., 1992. A Penman-Brutsaert model for wet surface evaporation. Water Resour. Res., 28, 121126.

Kim, J.H., Jackson, R.B., 2012. A global analysis of groundwater recharge for vegetation, climate, and soils. Vadose Zone J., 11, 1.

Kimball, B.A., Bellamy, L.A., 1986. Generation of diurnal solar radiation, temperature, and humidity patterns. Energy Agric., 5, 185-197.

Kuntz, D., Grathwohl, P., 2009. Comparison of steady-state and transient flow conditions on reactive transport of contaminants in the vadose zone. J. Hydrol., 369, 225-233.

Leterme, B., Mallants, D., Jacques, D., 2012. Sensitivity of groundwater recharge using climatic analogues and HYDRUS-1D. Hydrol. Earth Syst. Sci., 16, 2485-2497.

Marsaglia, G.W., Tsang, W., Wang, J., 2003. Evaluating Kolmogorov's distribution. J. Stat. Softw., 8, 18.

Marshall, J.D., Shimada, B.W., Jaffe, P.R., 2000. Effect of temporal variability in infiltration on contaminant transport in the unsaturated zone. J. Contam. Hydrol., 46, 151-161.

Maxwell, R.M., Kollet, S.J., 2008. Interdependence of groundwater dynamics and land-energy feedbacks under climate change. Nature Geosci., 1, 665-669.

Mileham, L., Taylor, R.G., Todd, M., Tindimugaya, C., Thompson, J., 2009. Climate change impacts on the terrestrial hydrology of a humid, equatorial catchment: sensitivity of projections to rainfall intensity. Hydrol. Sci. J., 54, 727-738.

Neto, D.C., Chang, H.K., van Genuchten, M.Th., 2016. A mathematical view of water table fluctuations in a shallow aquifer in Brazil. Ground Water, 54, 82-91.

Ngatcha, B.N., Mudry, J., Sarrot, R.J., 2007. Groundwater recharge from rainfall in the southern border of Lake Chad in Cameroon. World Appl. Sci. J., 2, 125-131. 
Owor, M., Taylor, R.G., Tindimugaya, C., Mwesigwa, D., 2009. Rainfall intensity and groundwater recharge: Empirical evidence from the Upper Nile Basin. Environ. Res. Lett., 4, 035009.

Phillips, F.M., 1994. Environmental tracers for water movement in desert soils of the American Southwest. Soil Sci. Soc. Am. J., 58, 15-24.

Portmann, F.T., Döll, P., Eisner, S., Flörke, M., 2013. Impact of climate change on renewable groundwater resources: assessing the benefits of avoided greenhouse gas emissions using selected CMIP5 climate projections. Environ. Res. Lett. 8, 024023.

Saifadeen, A., Gladnyeva, R., 2012. Modeling of solute transport in the unsaturated zone using HYDRUS-1D. TVVR 12/5020, Water Resources Engineering, Lund University, Sweden.

Santoni, C.S., Jobbágy, E.G., Contreras, S., 2010. Vadose zone transport in dry forests of central Argentina: Role of land use. Water Resour. Res., 46, W10541.

Scanlon, B.R., Healy, R.W., Cook, P.G., 2002. Choosing appropriate techniques for quantifying groundwater recharge. Hydrogeol. J., 10, 18-39.

Shah, T., Molden, D., Sakthivadivel, R., Seckler, D., 2000. The global groundwater situation: Overview of opportunities and challenges. IWMI Books, Rep. H025885. Int. Water Manage. Ins., Colombo, Sri Lanka.

Shiklomanov, I.A., 1997. Comprehensive assessment of the freshwater resources of the world. World Meteor. Org., Stockholm, Sweden.

Shiklomanov, I.A., Rodda, J.C., 2003. World Water Resources at the Beginning of the Twenty-First Century. Cambridge University Press, Cambridge, UK.

Šimůnek, J., Šejna, M., Saito, H., Sakai, M., van Genuchten, M.Th., 2013. The HYDRUS-1D Software Package for Simulating the One-Dimensional Movement of Water, Heat, and Multiple Solutes in Variably-Saturated Media, Version 4.17. Dep. of Environmental Sciences, University of California, Riverside, California, USA.

Šimůnek, J., van Genuchten, M.Th., Šejna, M., 2016. Recent developments and applications of the HYDRUS computer software packages. Vadose Zone J., 15, DOI: 10.2136/vzj2016.04.0033.

Soares, P.S.M., Souza, V.P., Possa, M.V., Soares. A.B., 2012. Projeto Cooperativo para Realização de Experimento de Avaliação de Desempenho de Cobertura Seca para Mitigação de Drenagem Ácida de Mina em Escala Piloto
Centro de Tecnologia Mineral (CETEM). Relatório Final de Projeto Elaborado Para a Carbonífera Criciúma S.A., Rio de Janeiro, Brazil.

Taylor, R.G., Todd, M.C., Kongola, L., Maurice, L., Nahozya, E., Sanga, H., MacDonald, A.M., 2013. Evidence of the dependence of groundwater resources on extreme rainfall in East Africa. Nature Climate Change, 3, 374-378.

van Bavel, C.H.M., 1966. Potential evaporation: The combination concept and its experimental verification. Water Resour. Res., 2, 3, 455-467.

van Bavel, C.H.M., Hillel, D.I., 1976. Calculating potential and actual evaporation from a bare soil surface by simulation of concurrent flow of water and heat. Agric. Meteorol., 17, 453-476.

van Genuchten, M.Th., 1980. A closed-form equation for predicting the hydraulic conductivity of unsaturated soils. Soil Sci. Soc. Am. J., 44 892-898.

Veldkamp, T.I.E., Wada, Y., Aerts, J.C.J.H., Ward, P.J., 2016. Towards a global water scarcity risk assessment framework: Incorporation of probability distributions and hydro-climatic variability. Environ. Res. Lett., 11, 024006.

Vero, S.E., Ibrahim, T.G., Creamer, R.E., Grandt, J., Healy, M.G., Henry, T., Kramers, G., Richards, K.G., Fenton, O., 2014. Consequences of varied soil hydraulic and meteorological complexity on unsaturated zone time lag estimates. J. Contam. Hydrol., 170, 53-67.

Vörösmarty, C.J., Green, P., Salisbury, J., Lammers, R.B., 2000. Global water resources: Vulnerability from climate change and population growth. Science, 289, 284-288.

Wada, Y., Wisser, D., Bierkens, M.F.P., 2014. Global modeling of withdrawal, allocation and consumptive use of surface water and groundwater resources. Earth Syst. Dyn., 5, 1540.

Wang, P., Quinlan, P., Tartakovsky, D.M., 2009. Effects of spatio-temporal variability of precipitation on contaminant migration in the vadose zone. Geophys. Res. Lett., 36, L12404.

Wann, M., Yan, D., Gold, H.J., 1985. Evaluation and calibration of three models for daily cycle of air temperature. Agric. Forest Meteorol., 34, 121-128.

Yin, Y., Sykes, J.F., Normani, S.D., 2015. Impacts of spatial and temporal recharge on field-scale contaminant transport model calibration. J. Hydrol., 527, 77-87.

Received 16 August 2017 Accepted 20 November 2017 